IBIMA Publishing

Journal of Eastern Europe Research in Business and Economics

http://ibimapublishing.com/articles/JEERBE/2017/253964/

Vol. 2017 (2017), Article ID 253964, 11pages

DOI: $10.5171 / 2017.253964$

Research Article

\title{
Romanian Erasmus Students' Flows-Gravity Model Approach
}

\author{
Anca Tamaş \\ Center of International Business and Economics, Bucharest University of Economic Studies, Romania \\ anca.tamas@rei.ase.ro
}

Received date: 13 February 2017; Accepted date: 23 May 2017; Published date: 8 August 2017

Academic Editor: Petr Dostál

Copyright (C) 2017. Anca Tamaş . Distributed under Creative Commons CC-BY 4.0

\begin{abstract}
The aim of this paper is to analyze the Erasmus students' flows between Romania and the partner countries in the period between 2004 and 2012 using the gravity model.The analysis was made in EViews. For the determination of the coefficients, panel data were used, with 8 cross-sections and 9 periods, respectively the period between 2004 and 2012 . The findings are similar with the ones in the previous studies: the GDP and the population have a positive effect on the Erasmus students' flows, the geographical distance and the cultural distance between two partner countries do not have a significant influence on the Erasmus students' flows and the linguistic similarity between the country of origin and the host country has a positive effect on the Erasmus students' flows.This paper is useful for the Romanian students, who are interested to know in which countries are other Romanian students and, also, for the Romanian and international universities, to find out which aspects they have to improve in order to be more attractive for the international students.
\end{abstract}

The main originality is the application of the gravity model on the Romanian Erasmus students' flows.

Keywords-gravity model, Romanian Erasmus students' flows

JEL Classification: F14 Empirical Studies of Trade; I23 Higher Education; Research Institutions

\section{Some Methodological Considerations}

Already recognized at the academic level, the gravity model is a methodological architecture, applied with success in economics, especially in the research focused on trade flows study, as well as in the case of other research methods. Although the gravity model is used with an increased frequency and for a number of years, the specialists didn't arrive to a consensus yet regarding its theoretical and methodological design.

The initial gravity model in economics was based on the Newton's universal gravity law, postulating that "every two particles are attracted one to each other with a force

Cite this Article as: Anca Tamaş (2017)," Romanian Erasmus Students' Flows-Gravity Model Approach", Journal of Eastern Europe Research in Business and Economics , Vol. 2017 (2017), Article ID 253964, DOI: $10.5171 / 2017.253964$ 
which is directly proportional with these two particles weights product and inversely proportional with the distance square between the two particles" (http://encyclopedia2.thefreedictionary.co $\mathrm{m} /$ ).

In 1962, the economics Nobel Prize laureate Jan Tinbergen used the gravity model for the trade flows extrapolation, considering the two particles as being two countries, the force with which are attracted one to each other as being the trade flows size, the weights of the two particles as being the size of the economics of the two countries and the distance between the two particles as being the distance between the two countries (Tinbergen, 1962).

\section{A Brief Diagnosis of Literature Review For The Gravitational Model:}

The initial model, designed by Tinbergen, was developed by Pöyhönen in 1963 and by Linnemann in 1967. Linnemann highlighted some methodological nature vulnerabilities of the initial model, insisting on the zeroes, on the fact that a lot of pairs of countries don't realize significant trade flows and this leads to the impossibility of logarithmating the data. Later, the model was improved, by adding at the mentionned variables other variables, like: the migration flows (Dunlevy \& Hutchinson, 1999), the exchange rate variation (Thursby \& Thursby, 1987), the international politics conflicts (Reuveny \& Kang, 2003) or the national politics boards (McCallum, 1995). A controverse regarding using logarithm in the multiplicative gravity equation, which is estimated using the Ordinary Least Squares Method, with the homoskedasticity hypothesis, is found at Santos Silva and Tenreyro (2006), Santos Silva, Joao and Tenreyro (2011), Gomez-Herrera (2013) and the use of nonlinear estimators was proposed.

Another controverse regarding the trade flows with the value 0 and, especially, how can we treat the zeroes in the econometric models, was brought into discution by Baldwin and DiNino (2006), Heckman (1979), Helpman, Melitz and Rubinstein (2008) and Rose and Spiegel (2004).
The geographical distance is much more important for the trade with services (exports and imports) than for the trade with goods. The trade with goods and the trade with services are favored by the dereglementation and the liberalization process, but the effect is more significant in the case of the trade with services (Kimura \& Lee, 2004) (Tamaş, A., 2016, unpublished PhD thesis).

The ERASMUS program is a European Union program in the education and professional formation domain, which was launched starting with the academic year 1987-1988 and which, since 2014, when it started a new multi-year financial perspective, it became Erasmus Plus. In this program, students from EU countries, as well as from other countries in Europe, as Norway, Island, Lichtenstein, Switzerland, Macedonia and Turkey, who are associated to this program, can study minimum three months and maximum an academic year in a partner university from the program. The countries with the most Erasmus possibilities were Spain, Germany, France and Italy and the countries which were the most attractive destinations in this program were Great Britain, Spain, France, Germany and Italy (http://ec.europa.eu/education).

\section{Literature Review for International Students:}

From the multitude of the scientific papers which had as research object this problem, I selected 80 scientific articles, which I structured in three sections: personal level, university level and country level. Each section was split into three sections: the beginning period 1980-1995, the period before the global economic crisis 19962007 and the period after crisis 2008-2013.

a)The analysis of the factors which action at personal level:

Regarding the first temporal interval taking into the analysis (1980-1995), the literature review is pretty weak, just Hooley and Lynch, in 1981, tried to proposed a model for the university choice.

The period before starting the negative phenomena, powered by the international 
economic and financial crisis (1996-2007) offers us more quality studies. The influence of different factors in choosing the international education was studied by Duan in 1997 and Shanka, Quintal and Taylor in 2005.

For the period following the global economic crisis (2008-2013), De Witt in 2011 and Phang in 2013 revealed the influence of the different factors which contribute to the decision of following study programmes abroad.

\section{b) The analysis of the factors which action at university level:}

In the beginning period (1980-1995), the first studies focused on global themes, such as the educational marketing (Nicholls et al, 1995), the alliances between the universities (Soutar \& Mazzarol, 1995) or using the advanced technologies (Hamer, 1993).

Regarding the period before the crisis (1996-2007), research continued to have the global determinants, such as the educational marketing (Czarniawska \& Genell, 2002) (Maringe, 2004), the operational foundations of the educational global market (Hemsley-Brown \& Oplatka, 2006) or the cross-cultural values (Hemsley-Brown \& Oplatka, 2004) as analytical vectors .

Regarding the period after the economic and financial crisis (2008-2013), the students' satisfaction and evaluation were studied by Engelke in 2008 and CubilloPinilla et. al. in 2009.

When we refer to the students' flows, we assume that the most wanted countries have the necessary infrastructure for affording to receive them and they are situated to a reasonable distance of their country of origin and through distance we don't understand just the geographical distance, we understand the cultural and the linguistic distance too, meaning that the student's country of origin and the country in which he/she came to study have similar cultural values and the language in which the study program takes place, generally English, is spoken by the majority of the people in the host country (Ivy, 2008).

\section{c) The analysis of the factors which action at country level:}

The careful study of the papers which were published in the beginning period (19801995) revealed that some researches focused on the idea of international education as a national industry and its influence on exports (McMahon, 1992) and the other studies focused on the idea of international students flows demand (Agarwal \& Winkler, 1985) (Lee \& Tan, 1984). Other authors focused on the students' accessibility to the quality support services (Edmond, 1995).

Regarding the period before the crisis (1996-2007), the number of the scientific papers which focused on this sensible subject grew. We can notice that international education become a dominant theme for a lot of analysts. Mazzarol determined the critical factors of success in 1998, Bourke identified a determinant model in 2000, Mazzarol and Hosie in 1996 and Mazzarol, Soutar and Seng in 2003 identified the most sustainable tendencies for the foreseeable future.

For the period after crisis (2008-2013), the main scientific research studies focused on the chosen country image (Gribble, 2008), on the aspects connected with the educational marketing (Lowrie \& HemsleyBrown, 2011) or on the sensible problem of ranking the universities or the study programs (Mechtenberg \& Strausz, 2012).

For the modeling of the Erasmus students' flows between Romania and the partner countries, an adaptation of the gravity model was used. The data are from Erasmus: Facts, Figures \& Trends European Union, http://ec.europa.eu/education/library/stu dy/2014/erasmus-impact_en.pdf.

The Erasmus students' flows between Romania and the partner countries for which the data are complete between 2004 and 2012 were chosen. 


\section{The evolution of the Romanian Erasmus students' number in the partner countries}

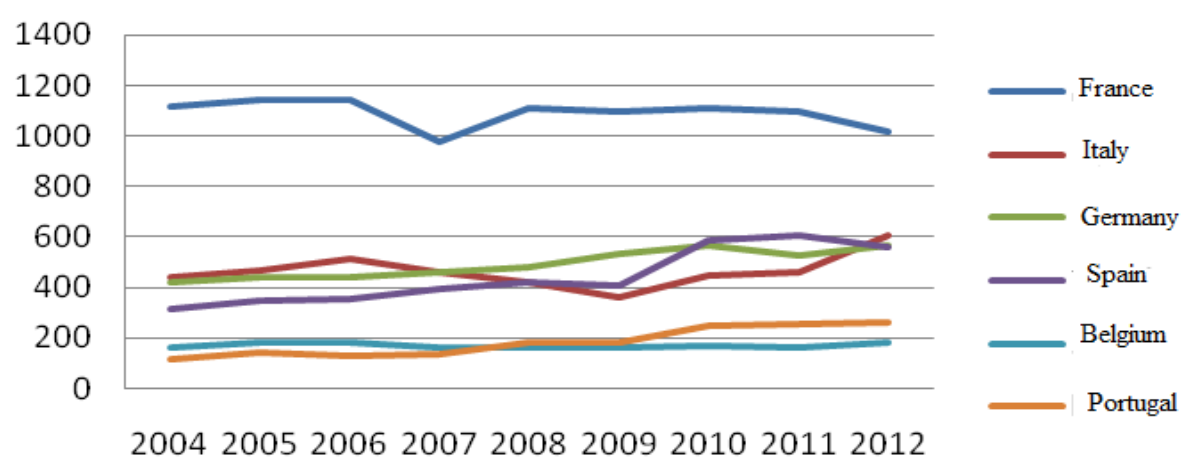

Fig 1. The dynamics of the Romanian Erasmus students' flows between 2004 and 2012 Source: Author's figure after processing the dates from http://ec.europa.eu/education

\section{The evolution of the Erasmus students' number who came in Romania}

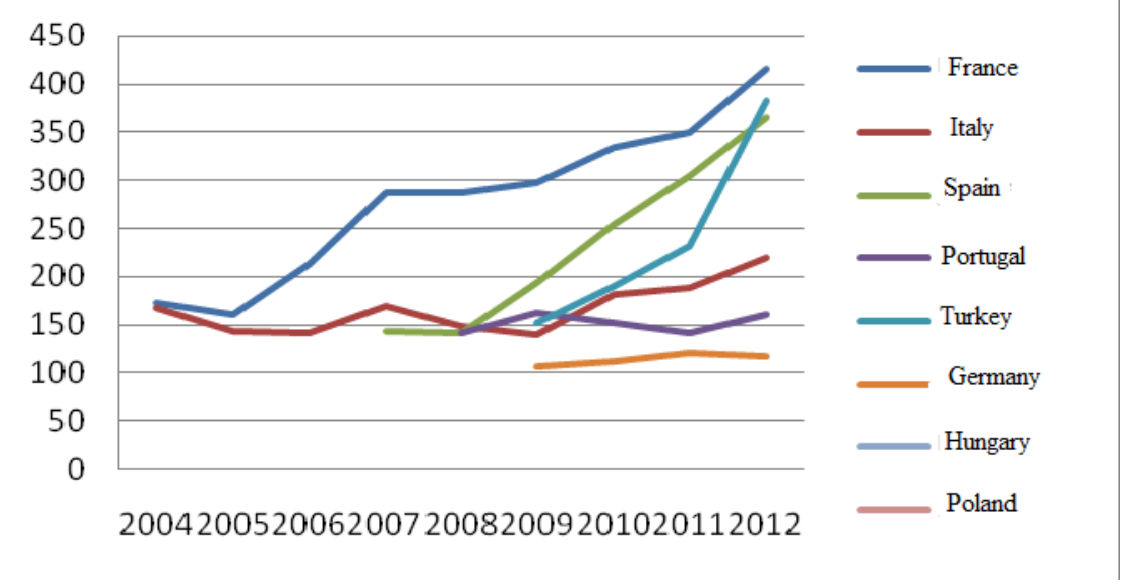

Fig 2: Dynamics of the Erasmus students' flows in Romania between 2004 and 2012

Source: Author's figure after processing the dates from http://ec.europa.eu/education

The most attractive countries for the Romanian Erasmus students in the analyzed period were France, the only country which attracted constantly over
100 students/academic year, Spain and Italy, which had a little fluctuant evolution of the number of students, remaining, however, at high cotes, Germany, with a 
constantly positive dynamics, Belgium and Portugal, with constant evolutions, but less numerous. To these countries were joined, from 2007 Great Britain, from 2008 Greece and from 2010 Hungary, Netherlands, Austria, Poland and Turkey, each of the mentioned countries attracting more than 100 students/year in the considered period.

Romania was in the same period the host of a more reduced number of Erasmus students, no more than 500 students/year, most of them having as country of origin France, Italy and Portugal, having evolutions relatively constant in this period, while the number of students from Spain and Turkey grew faster after 2008 and from 2012, Poland and Hungary joined too.

\section{The analytical hypotheseis are:}

H1: The GDP and the population have a positive effect on the Erasmus students' flows.

H2: The geographical distance and the cultural distance between two partner countries influence negatively the Erasmus students' flows.

H3: The linguistic similarity between the country of origin and the host country has a positive effect on the Erasmus students' flows.

The considered gravity model has as equation:

Ln FS $=\mathrm{c}_{0}+\mathrm{c}_{1} \ln \mathrm{GDP}+\mathrm{c}_{2} \ln \mathrm{POP}+\mathrm{c}_{3} \ln$ dist + $\mathrm{c}_{4}$ Indistcult $+\mathrm{c}_{5} \mathrm{LS}+\mathrm{c}_{6} \mathrm{RU}+\mathrm{c}_{7} \mathrm{SU}+\mathrm{e}$

Where:

- FS represents the students' flow, obtained by summing the Erasmus students from Romania with the Erasmus students who came to study in Romania. InFS is the dependent variable.

- InGDP represents the GDP of the partner countries, it's an independent variable, considered because a country with a high GDP has a bigger capacity for an adequate universitary infrastructure, which can afford to host a bigger number of international students, including Erasmus students. This variable is expected to have a positive influence, so, the 1 coefficient will be positive.

- InPOP represents the population of the partner countries, it's an independent variable, is expected to have a positive influence because, as bigger as the population of a country is, as bigger as the number of the students from this country is, so, there are bigger chances for a part of these students to become Erasmus students.

- InDIST is an independent variable, it represents the distance between the capitals of two partner countries. Usually, in the clasical gravity model, this variable has a negative influence, as bigger as the distance between two countries is, as less as the trade flow is. However, in the case of Erasmus students' flows, is expected to have a negative, but low influence, because the distances between the European countries are not very big.

- Lndiscult is an independent variable, it represents the cultural distance, it refers to the cultural distance between two countries, according to the components identified by Hofstede, calculated according to Pitagora's formula, in the opinion of White and Tadesse (2008) or Söderström (2008). It is expected to have a negative influence because, as bigger as the cultural distance between two countries is, as bigger as the shock of adaptation to the culture of the host country is, as well as the opposite shock, of re-adaptation to the country of origin culture. However, due to the reduced duration of the Erasmus studies, the influence of the cultural distance should be reduced too.

- LS is a dummy variable which takes the value 1 if the host country language is similar to the country of origin language and 0 in the rest of the cases. In the case of Romania, if it's a language from the latin family; we have to take into consideration the same aspect for the minorities' language too, that's why, for Hungary and for Germany is one too. This variable is 
expected to have a positive influence on the Erasmus students' flows, because a linguistic similarity affords to the Erasmus student a better and faster adaptation to the socio-cultural life from the host country.

- $\mathrm{RU}$ is a dummy variable which takes the value 1 if the host country has universities in top 50 which receive a big number of Erasmus students (RU=receiving universities) and 0 in the rest of the cases. This top is made every year by EU in the Erasmus program evaluation report. This variable is expected to have a positive value on the Erasmus students flow, because if a country has universities which receive a big number of Erasmus students, this aspect goes to the organizational and institutional capacity growth and affords this country to receive an at least equal number of Erasmus students in the future.

- $\quad \mathrm{SU}$ is a dummy variable which takes the value 1 if the host country has universities in top 50 which send a big number of Erasmus students in learning stages abroad (SU=sending universities) and 0 in the rest of the cases. This top is made every year by EU in the Erasmus program evaluation report. This variable is expected to have a positive influence on the Erasmus students flow not just due to the students effective infusion, but due to the development of some partnerships between the universities from different countries too.

- $\quad c 0, c 1, \ldots, c 7$ are the coefficients. As the independent variables are expressed in logarythms, the coefficients obtained through estimation can be considered as elasticities. In the previous studies, the coefficients for distance are, usually, between -0.7 and -1.7 and these associated with GDP and population are around 1 .

e represents the error factor.

For the determination of the coefficients, EViews and panel data were used, with 8 cross-sections, these already mentioned and 9 periods, respectively the period between 2004 and 2012. For regresion, EGLS (Estimated Generalized Least Squares) was used, with the options crossection weights (CW), period weights (PW) and, respectively, crossection SUR (CSUR), which afford heteroskedascticity and autocorrelation control. The results are presented in the following table: 
Table 1: The EGLS panel regression results for students

\begin{tabular}{|l|l|l|l|}
\hline & CW & PW & CSUR \\
\hline InGDP & $0.921290^{* * *}$ & $1.505485^{* * *}$ & $1.382101^{* * *}$ \\
& $(0.319114)$ & $(0.268544)$ & $(0.149594)$ \\
\hline InPOP & $0.769134^{* * *}$ & $0.672906^{* * *}$ & $0.794575^{* * *}$ \\
& $(0.075058)$ & $(0.067708)$ & $(0.046536)$ \\
\hline Indist & 0.065548 & -0.140545 & 0.057720 \\
& $(0.207682)$ & $(0.191840)$ & $(0.080821)$ \\
\hline Indistcult & $0.163983^{* *}$ & 0.063652 & $0.109206^{* *}$ \\
& $(0.067780)$ & $(0.047080)$ & $(0.051860)$ \\
\hline LS & $1.358307^{* * *}$ & $1.443856^{* * *}$ & $1.457901^{* * *}$ \\
& $(0.184165)$ & $0.191440)$ & $(0.130056)$ \\
\hline RU & $0.573913^{* *}$ & $0.701532^{* * *}$ & 0.001841 \\
& $(0.247331)$ & $(0.174434)$ & $(0.079083)$ \\
\hline SU & 0.083756 & -0.046570 & $0.450814^{* * *}$ \\
& $(0.207873)$ & $(0.158469)$ & $(0.143296)$ \\
\hline C & $-19.76687^{* * *}$ & $-22.36576^{* * *}$ & $-24.56539^{* * *}$ \\
& $(2.834973)$ & $(2.222015)$ & $(1.927486)$ \\
\hline R squared & 0.879117 & 0.890467 & 0.961044 \\
\hline R squared adjusted & 0.865245 & 0.877897 & 0.956573 \\
\hline F statistics & 63.37424 & 70.84391 & 214.9804 \\
& {$[0.000000]$} & {$[0.000000]$} & {$[0.000000]$} \\
\hline Jarque-Bera & 2.374549 & 2.690247 & 1.356878 \\
& {$[0.305052]$} & {$[0.260508]$} & {$[0.507409]$} \\
\hline
\end{tabular}

Source: Author's table on the EViews outputs

Note:

${ }^{* * *}$ significant at $1 \%$,

** significant at 5\%,

* significant at $10 \%$,

between the paranthesis ( ) the standard error,

between the paranthesis [ ] the probabilities for $F$ statistics and, respectively, for the Jarque-Bera test

\section{Some analytical considerations}

The H1 analitical hypothesis is supported, the coefficients for InPIB and, respectively, lnPOP, are statistically significant even at the level of $1 \%$, they have the expected positive sign and values between the admited values in the gravity model, respectively between 0.7 and 1.5. The results confirm that, a high GDP of the partner countries, which are host countries for the Erasmus students too, affords the development and the support of an academic infrastructure, universities, universitary campuses, students facilities, experience in the foreign students integration. A bigger population is, first, the base of a bigger number of own students, for whom the necessary universitary infrastructure must be assured, but, a bigger number of students means a bigger number of Erasmus students too. The obtained results prove the positive influence of the two variables on the Erasmus students flows and are according with the profile of the most important host countries which were revealed in the primary data analysis.

The H2 analytical hypothesis is rejected, the lndist coefficients are not statistically significant in either of the models, their sign is negative in the second model and positive in the rest of the models. The positive sign of the lndist coefficient is in contradiction with the classical gravity model, where a bigger distance between two countries influences negatively the trade flows between the two countries. But, this sign might be explained through the specific nature of the Erasmus program, the distances between the student's 
country of origin and the host country are not big, taking into consideration the fact that all the countries participated in the Erasmus program are in Europe. That's why, the distance does not have a significant influence on the Erasmus students flows, aspect confirmed by the fact that the obtained results are not statistically significant. The Indist coefficient is statistically significant in the models 1 and 3 , where it has a positive sign, in contradiction with the results from the classical gravity model, where the cultural distances between two countries cause the trade flows decrease. This result might be explained through the particular nature of the Erasmus program too, where the students choose to study in their domain, but in a different teaching system. And the choice of something different for a relatively short period, between 3 and 10 months, transforms the cultural distance from an impediment in an added value for the program.

The H3 analitical hypothesis is partially supported, the LS coefficient, linguistic similarity between the partner countries, is statistically significat in all the three models and has the expected positive sign, conforming the classical gravity model. The linguistic similarity coefficient value is the biggest in the models 1 and 3 and the second after the one of the GDP coefficient in the second model. This result is conforming with the previous ones and explains the fact that the linguistic similariry affords the Erasmus student a faster and more complex integration in the host country socio-cultural life and in the life outside the study hours and the university walls. The RU and SU coefficients are statistically significant at the $5 \%$ or $1 \%$ level in the first two models for RU, respectively in the third model for SU and have the expected positive sign, so, the two variables have a positive influence for the Erasmus students flows. The presence of the universities from a country in top 50 universities from the point of view of the Erasmus students received for RU, respectively sent with Erasmus scholarships for SU, has an indirect influence on the Erasmus students flows, it means gaining experience for universities and for students too. For CSUR model, for example, a growth with one procentual point of the host country GDP leads to a $1.38 \%$ growth of the Erasmus students flow ceteri paribus, while the fact that the partner countries have similar languages has as effect a $1.45 \%$ growth of the Erasmus students flow ceteri paribus. The $\mathrm{R}$ squared values show a high prediction accuracy, the $\mathrm{F}$ test probability shows the validity of the models, while the adjusted $\mathrm{R}$ squared values show that, between $86 \%$ and $95 \%$ from the dependent variable variation Erasmus students flows can be explained by the estimated equation.

The Jarque-Bera Test and the associate probabilities values show that the errors have a normal distribution.

\section{References}

1. Agarwal, V. B. and Winkler, D. R. (1985), 'Foreign Demand for United States Higher Education: A Study of Developing Countries in the Eastern Hemisphere', Economic Development and Cultural Change, 33 (3), 623-644.

2. Anderson, J. E. (2011), 'The Gravity model', Annual Review of Economics, 3, 133160.

3. Baldwin, R. and Di Nino, V. (2006), 'Euros and Zeros: The Common Currency Effect on Trade in New Goods', NBER Working Paper No. W12673.

4. Bourke, A. (2000), 'A Model of the Determinants of International Trade in Higher Education', The Service Industries Journal, 20 (1), 110-138

5. Cubillo-Pinilla, J. M., Zuniga, J., Losantos, I. S. and Sanchez, J. (2009), 'Factors Influencing International Students' Evaluations of Higher Education Programs', The Journal of American Academy of Business, Cambridge, 15 (1), 270-278.

6. Czarniawska, B. and Genell, K. (2002), 'Gone shopping? Universities on their way to the market', Scandinavian Journal of Management. [Online], [Retrieved January 22, 2017], 18(4), 455-474, http://econpapers.repec.org/article/eeesc aman. 
7. De Wit, H., (2011), 'Globalization and Internationalization of Higher Education' [introduction to online monograph]. Revista de Universidad y Sociedad del Conocimiento (RUSC). [Online], [Retrieved January 11, 2017], 8(2), 241-248, http://rusc.uoc.edu/ojs/index.php/rusc/ar ticle/view/v8n2-dewit/v8n2-dewit-eng.

8. Duan, J. P., (1997), 'The Influence of Various Factors on International Students In Selecting Universities: A South Australian Study of Chinese Students From Hong Kong and Malaysia', Ph.D. thesis, University of South Australia, Adelaide.

9. Dunlevy, J. A. and Hutchinson, W. K., (1999), 'The Impact of Immigration on American Import Trade in the Late Nineteenth and Early Twentieth Centuries', Journal of Economic History, 59 (4), 10431062.

10.Edmond, M. (1995), 'Quality support services for international students: AVCC code of ethical practices in the provision of education to overseas students by Australian higher education institutions', Journal of Tertiary Education Administration. 17 (1), 51-62.

11. Engelke,

M., (2008), 'Internationalization of the Swedish higher education system: An impact analysis on student and employee satisfaction', (Master dissertation), Blekinge Institute of Technology, Sweden, www.divaportal.se/smash/.../FULLTEXT01.pd...

12.Gómez-Herrera, E., (2013), 'Comparing alternative methods to estimate gravity models of bilateral trade', Empirical Economics, 44 (3), 1087-1111.

13.Gribble, C., (2008), 'Policy options for managing international student migration: The sending country's perspective', Journal of Higher Education Policy and Management, 30 (1), 25-39.

14.Hamer, G. A., (1993), 'The Use of Technology to Deliver Higher Education in the Workplace', Canberra: Department of Employment, Education and Training(DEET). [Online], [Retrieved
January 23, 2017], http://www.voced.edu.au/content/ngv:26 768

15.Heckman, J. J., (1979), 'Sample selection bias as a specification error', Econometrica, 47 (1) , 153-161.

16.Hemsley-Brown, J. and Oplatka, I., (2004), 'Research on school marketing: current issues and future directions', Journal of Educational Administration, 42 (3), 375-400.

17.Hemsley-Brown, J. and Oplatka, I., (2006), 'Universities in a competitive global marketplace: A systematic review of the literature on higher education marketing', International Journal of Public Sector Management, 19 (4), 316-338.

18.Helpman, E., Melitz, M. and Rubinstein, Y., (2008), 'Estimating trade flows: trading partners and trading volumes', Quarterly Journal of Economics, 123

a. (2), 441-487. [Online], [Retrieved January 28, 2017], https://dash.harvard.edu/bitstream/handl e/1/3228230/melitz_estimatingtradeflows .pdf?sequence=2.

19.Hooley, G. J. and Lynch, J. E., (1981), 'Modeling the student university choice process through the use of conjoint measurement techniques', European Research, 9 (4), 158-170.

20.Ivy, J., (2008), 'A new higher education marketing mix: the 7Ps for MBA marketing', International Journal of Educational Management, 22 (4), 288-299.

21.Kimura, F. and Lee, H.-H., (2004), 'The Gravity Equation in International Trade in Services', [Online], [Retrieved January 24, 2017]

http://cc.kangwon.ac.kr/ hhlee/paper/Ki mura-Lee-040831.pdf.

22.Lee, K. H. and Tan, J. P., (1984), 'The International Flow of Third Level Lesser Developed Country Students to Developed Countries: Determinants and Implications', Higher Education, 13 (6), 687-707. 
23.Linnemann, H., (1967), 'An Econometric Study of International Trade Flows', The Economic Journal, 77 (306), 366-368.

24.Lowrie, A. and Hemsley-Brown, J., (2011), 'This thing called marketisation', Taylor \& Francis Journal of Marketing Management, 27 (11-12), 1081-1086, [Online], [Retrieved January 11, 2017], http://epubs.surrey.ac.uk/728334.

25.Maringe, F. (2004), 'Vice chancellor's perceptions of university marketing: a view from universities in a developing country', Higher Education Review, 36 (2), 53-68.

26.Mazzarol, T., (1998), 'Critical success factors for international education marketing', International Journal of Educational Management, 12(4), 163-175.

27.Mazzarol, T. W. and Hosie, P., (1996), 'Exporting Australian Higher Education: Future Strategies in a Maturing Market.', Quality Assurance in Education, 4 (1), 37.

28.Mazzarol, T., Soutar, G. N. and Seng, M. S., (2003), 'The third wave: future trends in international education', International Journal of Educational Management, 17 (3), 90-99.

29.McCallum, J., (1995), 'National Borders Matter: Canada-U.S. Regional Trade Patterns', The American Economic Review, 85 (3), 615-623.

30.McMahon, M., (1992), 'Higher Education in a World Market. An historical look at the Global Context of International Study', Higher Education, 24 (4), 465-482.

31.Mechtenberg, L. and Strausz, R., (2012), 'Migration of the Talented: Can Europe Catch Up with the U.S.?', Journal of Public Economic Theory, Association for Public Economic Theory, 14(6), 945-969.

32. Nicholls, J., Harris, J., Morgan, E., Clarke, K. and Sims, D., (1995), 'Marketing higher education: the MBA experience', International Journal of Educational Management, 9 (2), 31 - 38.

33.Phang, S. L., (2013), 'Factors Influencing International Students' Study Destination
Decision Abroad', [Online], [Retrieved January 13, 2017], https://gupea.ub.gu.se/bitstream/2077/3 2136/1/gupea_2077_32136_1.pdf

34.Pöyhönen, P., (1963), 'A Tentative Model for the Volume of Trade Between Countries', Weltwirtchaftliches Archiv, 90, 93-100

35. Reuveny, R. and Kang, H., (2003), 'A Simultaneous-Equations Model of Trade, Conflict, and Cooperation', Review of International Economics, 11 (2), 279-295.

36.Rose, A. K. and Spiegel, M. M., (2004), 'A Gravity Model of Sovereign Lending: Trade, Default, and Credit', IMF Staff Papers, 51, [Online] [Retrieved February 4, 2017], https://www.imf.org/external/pubs/ft/sta ffp/2003/00-00/rs.pdf.

37.Santos S. J., Joao, M. C. and Tenreyro, S., (2011), 'Further simulation evidence on the performance of the Poisson pseudomaximum likelihood estimator', Economic Letters, 112 (2), 220-222.

38.Shanka, T., Quintal, V., and Taylor, R., (2005), 'Factors Influencing International Students' Choice of an Education Destination-A Correspondence Analysis', Journal of Marketing for Higher Education, 15 (2), 31-46.

39.Söderström, J., (2008), ‘Cultural Distance An Assessment of Cultural Effects on Trade Flows', Master Thesis, https://www.diva-

portal.org/smash/get/diva2:3799/FULLTE XT01.pdf.

40.Soutar, G. and Mazzarol, T. W., (1995), 'Gaining Competitive Advantage in Education Services Exports: Forward Integration and Strategic Alliances in a Maturing Market', Asia Pacific International Business: Regional Integration and Global Competitiveness, Perth, Murdoch University.

41.Tamaş, A., 2016, unpublished PhD thesis.

42.Thursby, J. G. and Thursby, M. C., (1987), 'Bilateral Trade Flows, the Linder 
Hypothesis and Exchange Risk', Review of Economics and Statistics, 69, 488-495.

43.Tinbergen, J., (1962), Shaping the World Economy; Suggestions for an International Economic Policy, Books (Jan Tinbergen), Twentieth Century Fund, New York.

44.White, R. and Tadesse, B., (2008), 'Cultural Distance and the US Immigrant-
Trade Link', The World Economy, 31 (8), 1078-1096.

45.http://ec.europa.eu/education.

46.http://ec.europa.eu/education/library/ study/2014/erasmus-impact_en.pdf.

47.http://encyclopedia2.thefreedictionary. com/ 